\title{
To Study the Microbial Changes of Herbal Lassi (Enriched with Honey and Tulsi (Ocimum sanctum Linn.) During Storage
}

\author{
Shashi Kumar, D.C. Rai, Himanshu Kumar Rai* and Saloni
}

Department of A. H \& Dairying, Institute of Agricultural Sciences, Banaras Hindu University, Varanasi-221005, India

*Corresponding author

\begin{tabular}{|c|c|}
\hline & A B S T R A C T \\
\hline & \multirow{5}{*}{$\begin{array}{l}\text { Milk production of India has increased significantly that it out spaced the global milk } \\
\text { production. } 7.0 \text { percent milk produced is converted to fermented dairy products. In our } \\
\text { present study, we prepared herbal Lassi enriched with honey and Tulsi extract. Honey is an } \\
\text { important and unique food product containing bioactive compounds derived from bees and } \\
\text { plants. Bioactive components in honey which confers health benefits includes a number of } \\
\text { flavonoids, phenolic acids, ascorbic acid, tocopherols, alkaloids, number of aromatic acids } \\
\text { and carotenoids. Ocimum sanctum popularly known as 'Tulsi' in Hindi and 'Holy basil' in } \\
\text { English is one of the sacred herb for Hindu in Indian subcontinent. It has versatile role to } \\
\text { play in traditional medicine. The combination of } 2.0 \text { percent Tulsi extract and } 10.0 \text { percent } \\
\text { honey was considered to be the most appropriate level for manufacturing of herbal honey } \\
\text { Lassi. During storage studies average lactobacilli count, streptococci count, yeast and mold } \\
\text { count was found } 9.06 \mathrm{log} \mathrm{CFU} / \mathrm{g}, 8.27 \text { log CFU/g and } 2.18 \text { log CFU/g respectively for } \\
\text { herbal Lassi. Coliform count was found absent during entire storage period. }\end{array}$} \\
\hline $\begin{array}{l}\text { Ke y w o r d s } \\
\text { Fermented, Honey, } \\
\text { Tulsi, Herbal, Lassi }\end{array}$ & \\
\hline Article Info & \\
\hline $\begin{array}{l}\text { Accepted: } \\
\text { 15 July } 2018 \\
\text { Available Online: } \\
10 \text { August } 2018\end{array}$ & \\
\hline & \\
\hline
\end{tabular}

\section{Introduction}

India as the 'Oyster' of the global dairy industry that provides opportunities galore for the entrepreneurs globally. Since last 15 years, India continues to be the largest producer of milk in the world. India has outpaced the global milk production with an annual growth rate of 5.53 percent compared with the 2.09 percent achieved globally. Milk production has increased significantly to 164 million tones in 2016-17. India's milk production in 2016-17 rose by 18.81 percent as compared to 2013-14. Similarly, the per capita availability of milk increased to 351 gin 2016-17.Lassi, is a popular beverage in the western and northern states of India. It is popular for its pleasant taste, cooling and thirst quenching properties and therapeutic value. It has creamy consistency, sweetish rich aroma and mild to acidic flavour, which makes the product refreshingly palatable. On an average Lassi may have fat from 3.0-3.5 percent, total solids 16-18 percent and acidity varying from $0.75-0.88$ percent (De, 2004; Mathur et al., 2005). Lassi has been mentioned as one of the best among milk products due to its immense therapeutic and nutritional value (Sarkar, 2008). Regular use of Lassi immensely helps the jaundice and 
alcoholic liver patients to regain normal appetite and digestion (Trivedi, 1971; Shashtri, 1974; and Anon, 2003).

In the process of development of Herbal lassi, we have enriched it with Tulsi (Ocimum sanctum Linn.) and Honey as sweetner. Ocimum sanctum popularly known as 'Tulsi' in hindi and 'Holy basil' in English is one of the sacred herb for hindu in Indian subcontinent. It has versatile role to play in traditional medicine. Within Ayurveda, Tulsi is known as "The Incomparable One" "Mother Medicine of Nature" and "The Queen of Herbs" and is revered as an "Elixir of life" that is without equal for both its medicinal and spiritual properties. A number of active constituents responsible for the medicinal actions of Tulsi (Ocimum sanctum Linn.) have been isolated and are being characterized. Tulsi (Ocimum sanctum Linn.) leaves contain 0.7 percent volatile oil comprising about 71.0 percent Eugenol and 21.0 percent Methyl Eugenol. These studies reveal that Tulsi has a unique combination of actions that include: Antimicrobial (including antibacterial, antiviral, antifungal, antiprotozoal, antimalarial, anthelmintic), mosquito repellent, anti-diarrheal, antioxidant, anti-cataract, anti- inflammatory, chemo preventive, radioprotective, hepatoprotective, neuro-protective, cardioprotective, anti-diabetic, antihypercholesterolemia, anti-hypertensive, anticarcinogenic, analgesic, anti-pyretic, antiallergic, immunomodulatory, central nervous system depressant, memory enhancement, anti-asthmatic, anti-tussive, diaphoretic, antithyroid, anti-fertility, anti-ulcer, anti-emetic, anti-spasmodic, anti- arthritic, adaptogenic, anti-stress, anti-cataract, anti-leukodermal and anti-coagulant activities. These pharmacological actions help the body and mind cope with a wide range of chemical, physical, infectious and emotional stresses and restore physiological and psychological function.
Honey is an important and unique food product containing bioactive compounds derived from bees and plants. Bioactive components in honey which confers health benefits includes a number of flavonoids, phenolic acids, ascorbic acid, tocopherols, alkaloids, number of aromatic acids and carotenoids. It is composed primarily of fructose and glucose but also contains 4 to 5 percent fructo-oligosaccharides which serve as prebiotic agents (Chow, 2002). It contains more than 180 substances, including amino acids, vitamins, minerals and enzymes (White, 1979). Honey is a supersaturated sugar solution with a low water activity $\left(a_{w}\right)$, which does not support the growth of bacteria and yeast. Natural acidity of honey inhibits many pathogens.

\section{Materials and Methods}

The experiment studies were conducted in the department laboratory, Department of Animal Husbandry and Dairying, Institute of Agricultural Sciences, Banaras Hindu University, Varanasi (U.P.) India. The objective of the present study is to increase the functional value of Lassi by incorporation of honey and Tulsi (medicinal herb) that make it more useful and acceptable to undertake its commercial production.

\section{Preliminary trials}

\section{The treatments used for present study of} sensory evaluation

\begin{tabular}{|l|l|}
\hline $\mathrm{T}_{0}$ & $100 \%$ Lassi $+0 \%$ \%oney+ 0\% Tulsi extract \\
\hline $\mathrm{T}_{1}$ & $100 \%$ Lassi $+6 \%$ honey $+2 \%$ Tulsi extract \\
\hline $\mathrm{T}_{2}$ & $100 \%$ Lassi $+8 \%$ honey $2 \%$ Tulsi extract \\
\hline $\mathrm{T}_{3}$ & $100 \%$ Lassi $+10 \%$ honey $+2 \%$ Tulsi extract \\
\hline $\mathrm{T}_{4}$ & $100 \%$ Lassi $+12 \%$ honey $+2 \%$ Tulsi extract \\
\hline
\end{tabular}

Optimization was done on the basis of sensory score and Lassi with $2 \%$ Tulsi and $10 \%$ honey was found most suitable on the basis of sensory score. 


\section{Microbial analysis of herbal honey lassi}

Preparation of herbal honey Lassi Samples for microbial analysis: $11 \mathrm{~g}$ of Herbal honey Lassi sample was aseptically pipetted out and transferred to $99 \mathrm{ml}$ phosphate buffer dilution blank to obtain 1:10 dilution. Subsequently, 1 $\mathrm{ml}$ of above dilution was used for making further dilutions in $9 \mathrm{ml}$ phosphate buffer tubes. Suitable dilutions were prepared and poured in a set of sterile Petri dishes in duplicates (Fig. 2).

Lactobacilli count: Petri plates with one $\mathrm{ml}$ of appropriate serial dilutions of the samples were prepared as described above and $1 \mathrm{ml}$ from selected dilutions was poured in duplicate plates and mixed with tempered MRS medium. After setting of the agar, another layer of the same medium $(5-7 \mathrm{ml})$ was poured. The plates were then incubated at $37+2{ }^{\circ} \mathrm{C}$ for $72 \mathrm{~h}$. After incubation, plates were removed for counting the colonies. The lactobacilli count was expressed as $\mathrm{CFU} / \mathrm{g}$.

Streptococci count: For streptococci count, serial dilutions of the samples were prepared as described above and $1 \mathrm{ml}$ from selected dilutions was poured in duplicate plates and mixed with tempered M17 medium. After setting of the agar, another layer of the same medium (5-7 $\mathrm{ml})$ was poured. The plates were then incubated at $37+2^{\circ} \mathrm{C}$ for $48 \mathrm{~h}$. After incubation, plates were removed for counting the colonies. The Streptococci count was expressed as CFU/g (IS: 1479, Part III,1962).

Yeast and mould count: The petri plates containing the diluted samples were poured with melted and cooled potato dextrose agar medium at around $45^{\circ} \mathrm{C}$ (adjusted to $\mathrm{pH} 3.5$ using $10 \%$ sterile tartaric acid solution, within $30 \mathrm{~min}$ of addition to the sample) mixed properly, and allowed to solidify. The plates were incubated at temperature $22-25^{\circ} \mathrm{C}$ for 3-5 days before count were recorded (IS: 5403, 1969).
Coliform count: Serial dilutions of the samples were prepared as described above and $1 \mathrm{ml}$ from selected dilutions was poured in duplicate plates and mixed with tempered VRBA medium. After setting of the agar, another layer of the same medium $(5-7 \mathrm{ml})$ was poured. The plates were then incubated at $37+2{ }^{\circ} \mathrm{C}$ for $24 \mathrm{~h}$. After incubation, plates were removed for counting dark red colonies having a diameter of $>0.5 \mathrm{~mm}$ size. The coliform count was expressed as CFU/g (IS: 5401, 1969).

\section{Statistical analysis}

All the parameters under study were analyzed by statistical methods. Optimization study data were analyzed by Completely Randomized Design as per the methods described by Steel and Torrie (1980). Storage study data were examined using Factorial $\mathrm{CRD}$. The values for microbial counts were $\log$ transformed before analysis.

\section{Result and Discussion}

\section{Storage study for herbal honey Lassi}

Based on preliminary trials on growth curve as well as overall higher sensory scores in terms of flavor, colour and appearance and overall acceptability, we decided to take further trials for shelf-life study with a product incorporated with $10 \%$ honey and $2 \%$ Tulsi extract (Fig. 1). Even though nonsignificant, the count of lactobacilli and streptococci were also relatively lower in $10 \%$ honey and 2\% Tulsi extract added samples. The shelf-life of the product added with 10\% honey, designated as herbal honey Lassi (T) was studied by storage at $7 \pm 1^{\circ} \mathrm{C}$ and compared with a control product prepared without honey, designated as Control (normal) Lassi (C). The shelf- life was monitored by chemical, microbiological and sensory attributes. 
Microbiological changes during shelf-life study

\section{Change in lactobacilli count}

Lactobacilli count was comparatively higher $(\mathrm{P}<0.05)$ in normal Lassi $(9.06 \log \mathrm{CFU} / \mathrm{g})$ as compared to herbal honey Lassi (8.72 log $\mathrm{CFU} / \mathrm{g}$ ). For normal Lassi the count varied from 9.24 to $8.65 \log \mathrm{CFU} / \mathrm{g}$ while herbal honey Lassi showed a decline from 8.87 to $8.46 \log \mathrm{CFU} / \mathrm{ml}$ during storage for 28 days. According to statistical analysis, control sample showed significant increase in Lactobacilli count till 7 th day of storage. Subsequently, up to 14th day, effect was significant followed by non-significant effect on 21st and 28th day. Herbal honey Lassi showed non- significant increase in lactobacilli count followed by significant decrease in count and thereafter the changes were non-significant till 28th day of storage.
The changes in $\mathrm{pH}$ of control (C) and Herbal honey Lassi ( $\mathrm{T}$ ) stored at refrigerated temperature are depicted in Table 1 and figure 3.

\section{Changes in Streptococci count}

Streptococci count of control Lassi (C) was marginally higher than that of herbal honey Lassi (T).

For control Lassi, the count gradually decreased from 8.56 to $7.98 \log$ CFU/g during storage for 28 days whilst herbal honey Lassi showed a decline in count from 8.46 to 7.43log CFU/g, upto 7th day and thereafter again a reduction was observed from 7 thday to 28thday i.e., from 7.43 to $7.83 \mathrm{log} \mathrm{CFU} / \mathrm{g}$. The changes in $\mathrm{pH}$ of control (C) and Herbal honey Lassi (T) stored at refrigerated temperature are depicted in Table 2 and figure 4.

Table.1 Changes in Lactobacilli count of control sample (Normal Lassi) and optimized herbal honey Lassi during storage at $7 \pm 1^{\circ} \mathrm{C}$

\begin{tabular}{|c|c|c|c|c|c|c|}
\hline Treatment & 0 Day & 7 Days & 14 Days & 21 Days & 28 Days & $\begin{array}{c}\text { Treatment } \\
\text { mean }\end{array}$ \\
\hline $\mathrm{T}$ & 8.87 & 9.04 & 8.72 & 8.46 & 8.46 & $\mathbf{8 . 7 2}$ \\
\hline $\mathrm{C}$ & $\mathbf{9 . 2 4}$ & $\mathbf{9 . 4 6}$ & $\mathbf{9 . 0 5}$ & $\mathbf{8 . 8 1}$ & $\mathbf{8 . 6 5}$ & $\mathbf{9 . 0 6}$ \\
\hline
\end{tabular}

${ }^{*} \mathrm{C}$ Represents control sample (Normal Lassi). ${ }^{*}$ T represents treated sample (i.e., $100 \mathrm{ml} \mathrm{Lassi}+10 \%$ honey $+2 \%$ Tulsi)

Table.2 Changes in Streptococci count of control sample (Normal Lassi) and treated sample (Herbal honey Lassi) during storage at $7 \pm 1^{\circ} \mathrm{C}$

\begin{tabular}{|c|c|c|c|c|c|c|}
\hline Treatment & 0 day & 7 days & 14 days & 21 days & 28 days & $\begin{array}{l}\text { Treatment } \\
\text { mean }\end{array}$ \\
\hline $\mathrm{C}$ & 8.56 & 8.46 & 8.39 & 8.16 & 7.98 & 8.34 \\
\hline $\mathrm{T}$ & 8.46 & 8.43 & 8.35 & 8.06 & 7.83 & 8.27 \\
\hline $\begin{array}{l}\text { Period } \\
\text { mean }\end{array}$ & 8.61 & 8.44 & 8.37 & 8.11 & 7.99 & \\
\hline
\end{tabular}


Table.3 Changes in yeast and mold count of Control Lassi and herbal honey Lassi during storage at $7 \pm 1{ }^{\circ} \mathrm{C}$

\begin{tabular}{|c|c|c|c|c|c|c|}
\hline Treatment & $\begin{array}{r}0 \\
\text { Days }\end{array}$ & 7 Days & 14 Days & $\begin{array}{r}21 \\
\text { Days }\end{array}$ & $\begin{array}{c}\text { Treatment } \\
\text { mean }\end{array}$ \\
\hline C & 2.18 & 2.28 & 3.41 & 3.46 & 2.93 & $\mathbf{2 . 8 5}$ \\
\hline T & $\mathbf{1 . 5 9}$ & $\mathbf{1 . 9 8}$ & $\mathbf{2 . 6 4}$ & $\mathbf{2 . 6 0}$ & $\mathbf{2 . 0 9}$ & $\mathbf{2 . 1 8}$ \\
\hline
\end{tabular}

${ }^{*}$ C Represents control sample (Normal Lassi). ${ }^{*} \mathrm{~T}$ represents treated sample (i.e., $100 \mathrm{ml}$ Lassi $+10 \%$ honey $+2 \%$ Tulsi)

Figure.1 Flow diagram for the preparation of herbal extract

\section{Method of Tulsi leaf extraction}

\section{Weighed $50 \mathrm{~g}$ of Tulsi leaves}<smiles>[AlH2]</smiles>

Washed with water and dried with muslin cloth

Crushed in mixer by adding $50 \mathrm{ml}$ of distilled water

$\downarrow$

Collected extract by pressing the mass through muslin cloth

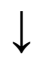

Adjusted TS with distilled water (2.0\%)

$\downarrow$

Used the extract for preparation of herbal drink

Figure.2 Flow diagram for the preparation of herbal honey Lassi

\section{Preparation of Herbal honey Lassi}

Receiving of fresh cow milk

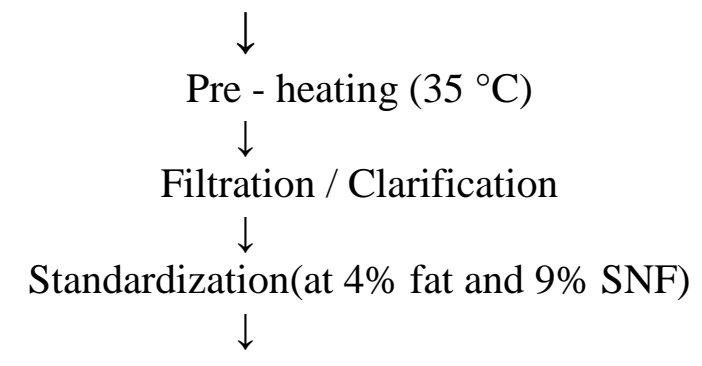




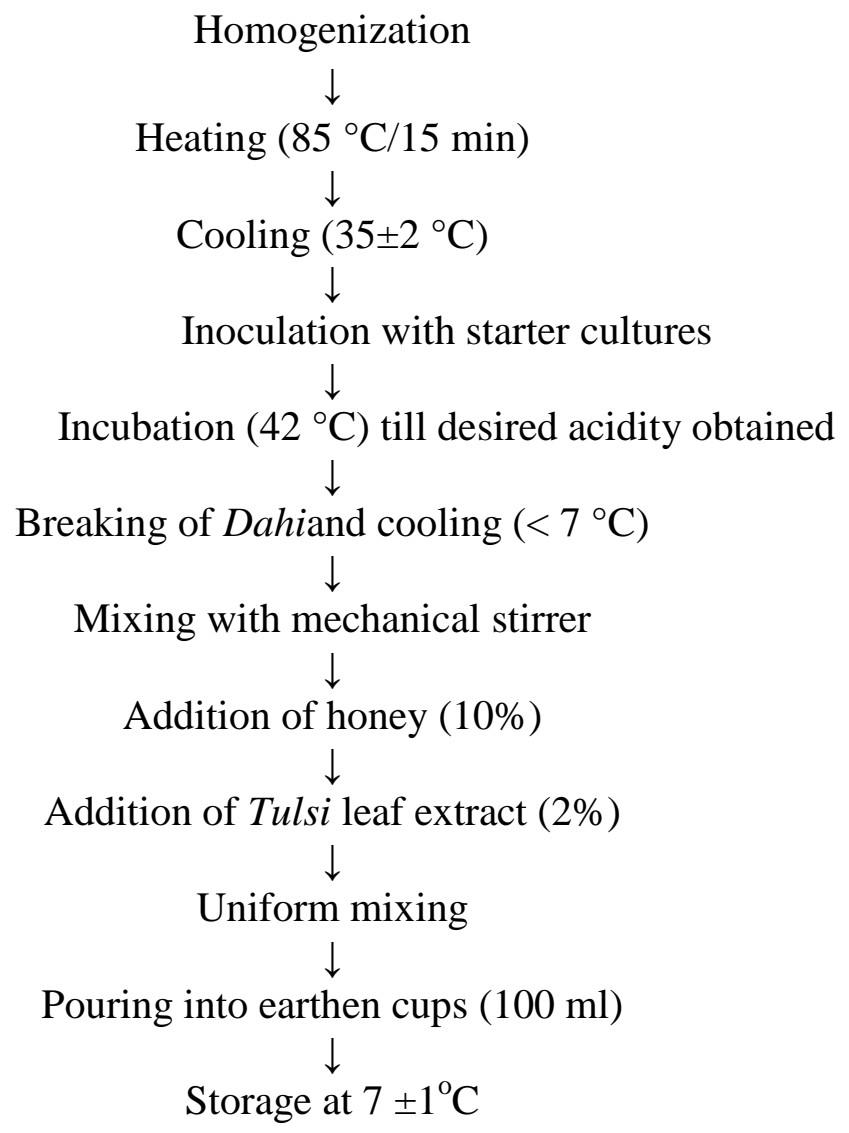

Figure.3 Changes in Lactobacilli count of control sample (Normal Lassi) and optimized herbal honey Lassi during storage at $7 \pm 1^{\circ} \mathrm{C}$

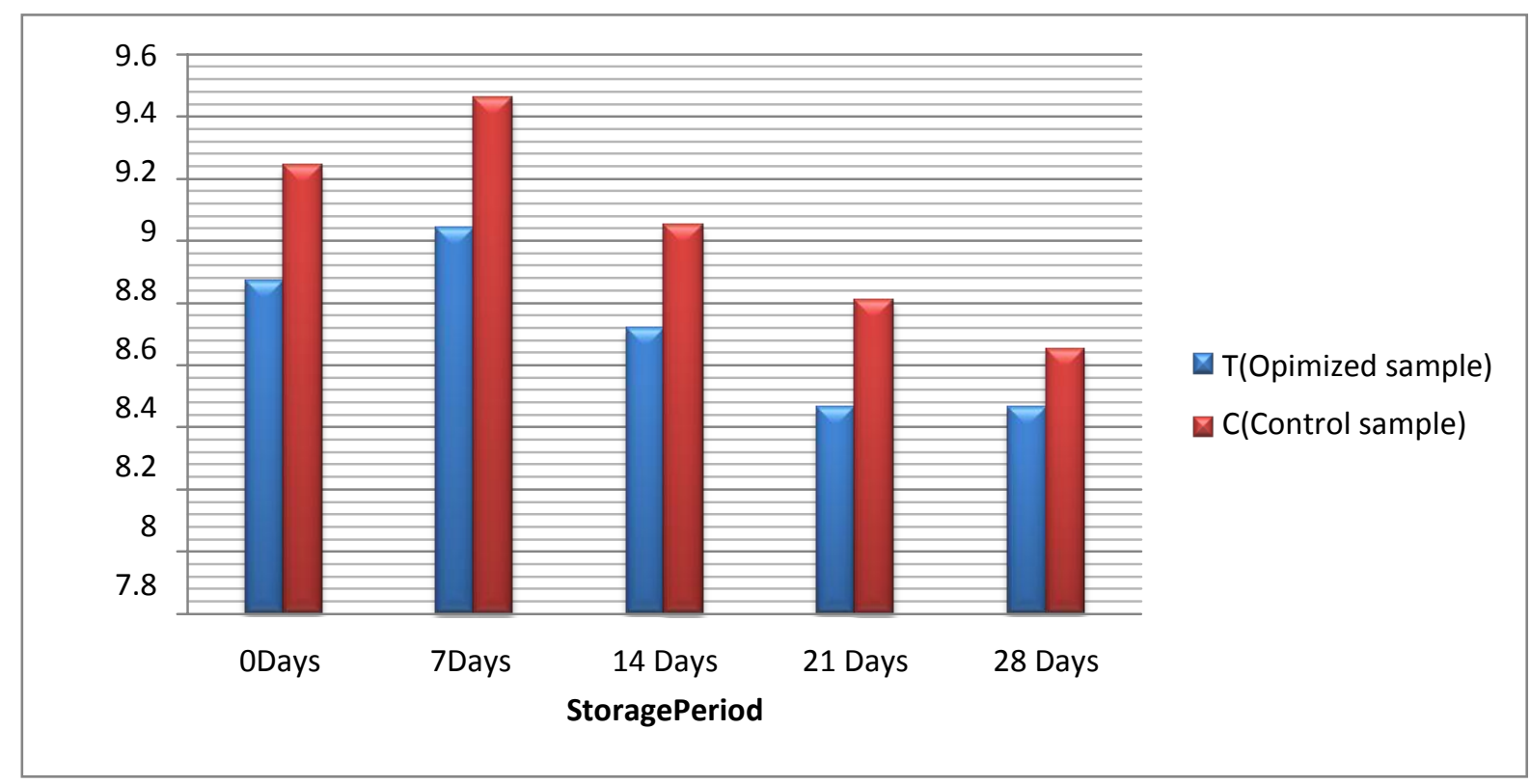


Figure.4 Changes in Streptococci count of Control sample (Normal Lassi) and Treated sample (Herbal honey Lassi) during storage at $7 \pm 1^{\circ} \mathrm{C}$

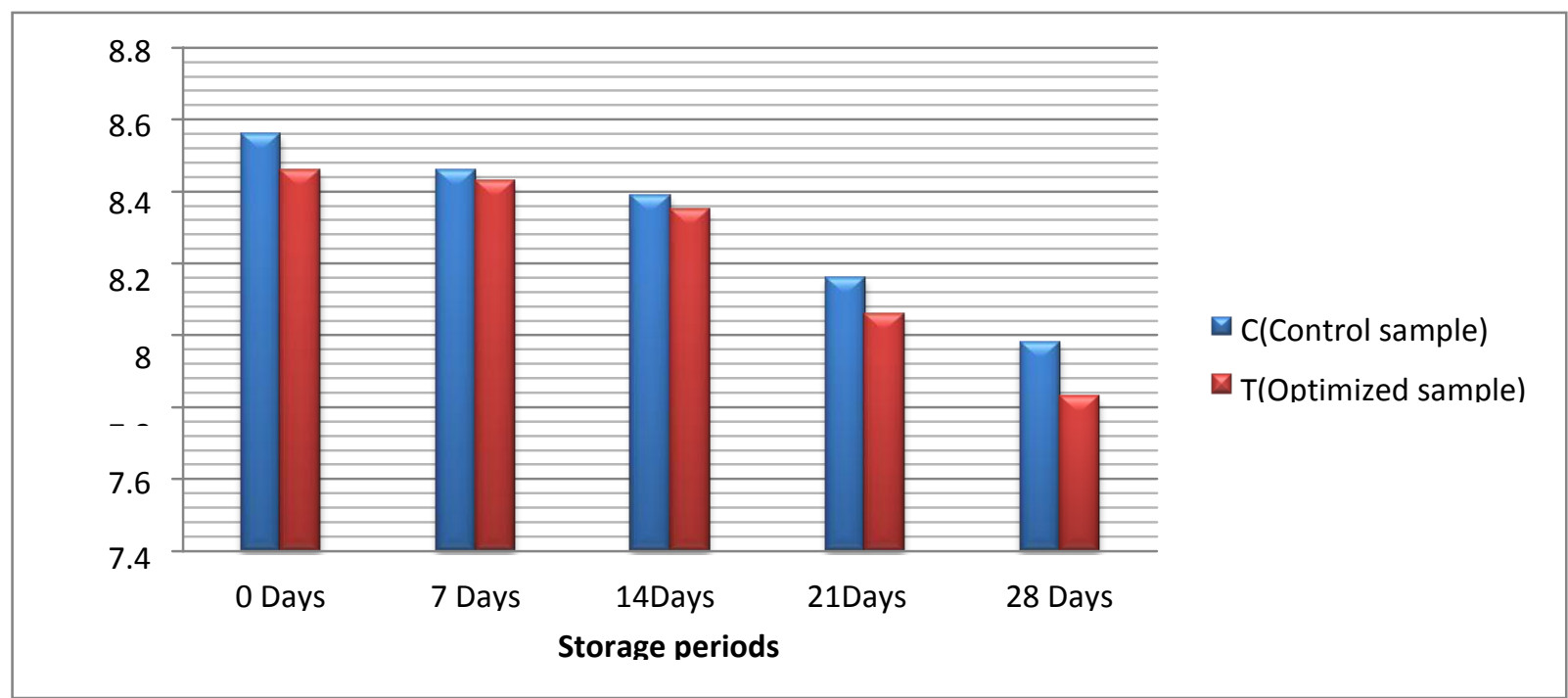

Figure.5 Changes in yeast and mold count of Control Lassi and herbal honey Lassi during storage at $7 \pm 1{ }^{\circ} \mathrm{C}$

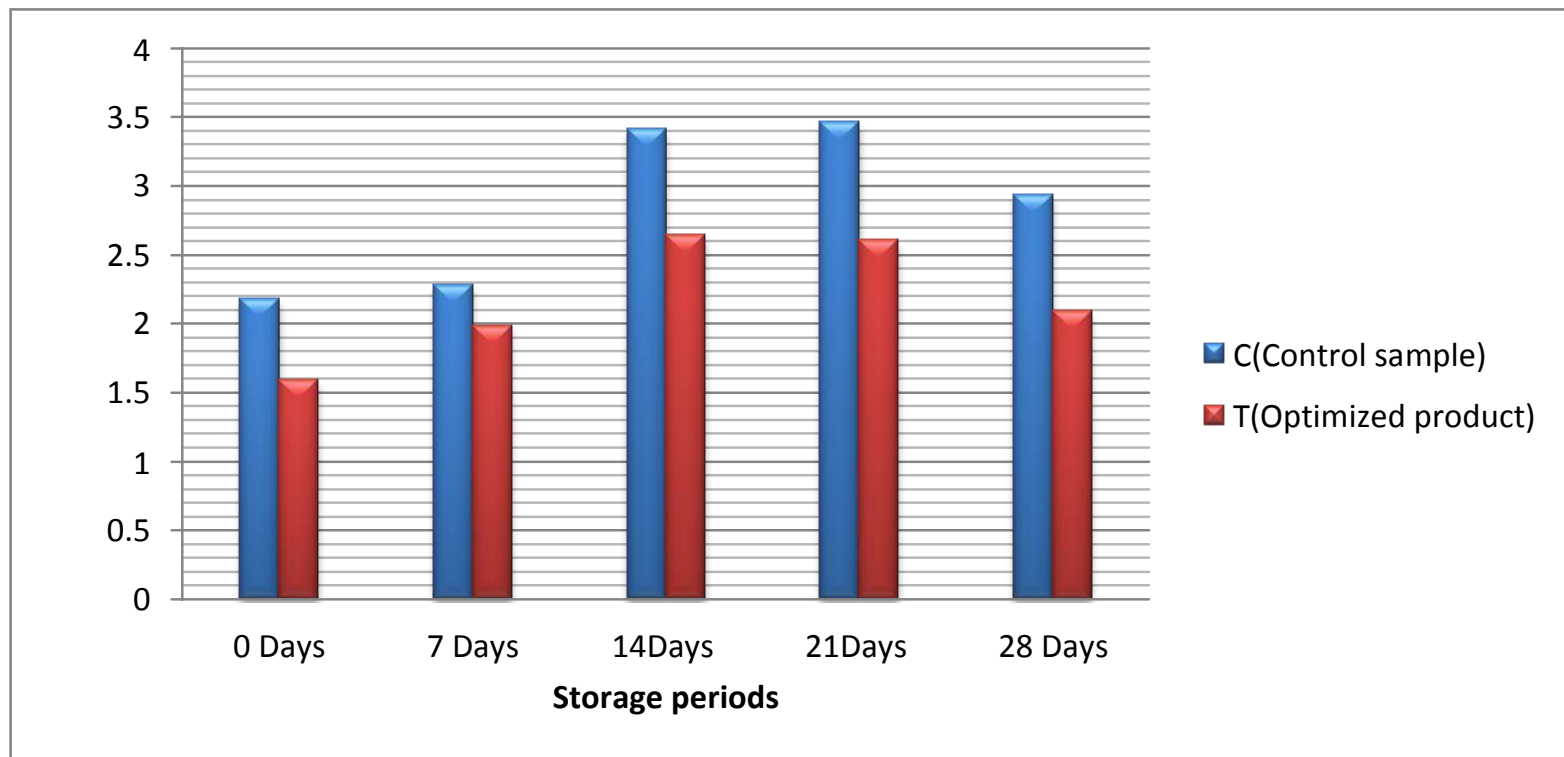

\section{Changes in yeast and mold count}

Yeast and mold count shows a significant increase from $7^{\text {th }}$ day to $21^{\text {st }}$ day i.e., 2.18 to $3.46 \log \mathrm{CFU} / \mathrm{g}$ and thereafter count decreases upto $28^{\text {th }}$ day i.e. 3.46 to $2.93 \log \mathrm{CFU} / \mathrm{g}$. While the herbal Lassi shows gradual increase in yeast and mold count from $0^{\text {th }}$ to $21^{\text {st }}$ day. And after that decreases significantly to $2.09 \log \mathrm{CFU} / \mathrm{g}$. On an average control lassi having yeast and mold count 2.85 log $\mathrm{CFU} / \mathrm{g}$ during entire storage period and herbal lassi having $2.18 \mathrm{log}$ 
CFU/g during entire storage period. The changes in yeast and mold of control (C) and Herbal honey Lassi (T) stored at refrigerated temperature are depicted in Table 3 and figure 5 .

\section{Changes in coliform count}

Coliforms are opportunistic pathogens, which generally indicate hygiene and post pasteurization contamination. Their presence in fermented milk depends on the type of culture used for product manufacturing as well as the initial acidity of the product. Coliform was found to be absent (in $1 \mathrm{~g}$ ) in both control sample (normal Lassi) and herbal Lassi throughout the storage study of 28 days.

In conclusion, the present study was attempted to develop Herbal Lassi by incorporation of honey and Tulsi extract. The combination of 2.0 percent Tulsi extract and 10.0 percent honey was considered to be the most appropriate level for manufacturing of herbal honey Lassi. The experiment studies were conducted in the department laboratory, Department of Animal Husbandry and Dairying, Institute of Agricultural Sciences, Banaras Hindu University, Varanasi (U.P.), India. The findings of present study are summarized as under:

During microbial study, it was found that, Total viable lactobacilli count was 8.87 to 8.46 $\log \mathrm{CFU} / \mathrm{g}$ in control Lassi while in herbal honey Lassi it varied from 9.24 to $8.65 \mathrm{log}$ $\mathrm{CFU} / \mathrm{g}$, respectively at the end of storage. Streptococci count varied from 8.46 to $7.83 \mathrm{log}$ $\mathrm{CFU} / \mathrm{g}$ in herbal honey Lassi whereas a decrease from 8.56 to $8.98 \mathrm{log} \mathrm{CFU} / \mathrm{g}$ was observed in control. The yeast and mold count was significantly lower in herbal honey Lassi than control during storage. Coliforms were absent (in $1 \mathrm{~g}$ ) in both control (normal) and herbal honey Lassi throughout storage period.

\section{References}

Chow, J. (2002). Probiotics and prebiotics: a brief overview. Journal of Renal Nutrition. 12:76-86.

De, S.K. (2004). Indian Dairy Product In: Outlines of Dairy technology. Oxford University Press.463.

Indian Standards (1962). IS: 1479. Method of test for Dairy industry. Part III. Bacteriological Examination of Milk. Indian Standards Institution, New Delhi.

Indian Standards (1969). IS: 5403. Methods for yeast and mold count of food stuffs. Indian Standard Institution, New Delhi.

Indian Standards (1969). IS: 5401. Methods for detection and estimation of coliform bacteria in foodstuffs.

Mathur, M.P., Datta Roy, D. and Dinakar,P. (2005).Chemistry of Milk Products In: Textbook of Dairy Chemistry. ICAR publication. 290.

Molan, P.C. (1992). The antibacterial activity of honey. 1. The nature of antibacterial activity. Bee World. 73: 5-28.

Molan, P.C. (1992). The antibacterial activity of honey. 1. The nature of antibacterial activity. Bee World. 73: 5-28.

Sarkar, S. (2008) Innovations in Indian fermented milk products - a review Food Biotechnology 221: 78-97.

Shashtri, G.M. (1974). "Charak Samhita" Sastu Sahitya Vardhak Karyalaya, Bombay.

Trivedi, J.L. (1971). Family Medicine. (Gharvaidu). 4th Edition J. M. Mehta Publication, Bombay, pp. 20 - 26.

\section{How to cite this article:}

Shashi Kumar, D.C. Rai, Himanshu Kumar Rai and Saloni. 2018. To Study the Microbial Changes of Herbal Lassi (Enriched with Honey and Tulsi (Ocimum sanctum Linn.) During Storage. Int.J.Curr.Microbiol.App.Sci. 7(08): 2750-2757. doi: https://doi.org/10.20546/ijcmas.2018.708.288 